\title{
Vigésimo Quinto Aniversario del \\ Instituto de Estudios Internacionales \\ de la Universidad de Chile*
}

\author{
María Teresa Infante Caffi
}

Un cuarto de siglo es una ocasión que justificaría plenamente una visión positiva del pasado y una celebración del tiempo que viene llena de buenas intenciones y deseos. Trataré de situar nuestro aniversario en un marco de realismo, al mismo tiempo que de confianza.

El Instituto fue creado en 1966 en una época de optimismo, al que contribuía la presencia de destacados profesionales, funcionarios y organizaciones internacionales, quienes visualizaban un nuevo espacio para América Latina en el escenario internacional. Inspiraban las teorías acerca del sistema internacional en que la estratificación de los países y los problemas del desarrollo eran los centrales. Su fundación, dentro de la Universidad de Chile, con el apoyo de su Consejo, respondió a una iniciativa pionera de quien fue su primer director, el profesor Claudio Véliz, hoy presente en este acto.

Ciertos rasgos que identificaron en sus orígenes a este centro académico no se han desvirtuado, lo cual ha permitido en ocasiones de crisis, reanimar o revivir un proyecto académico caracterizado por la independencia, el rasgo personal de las contribuciones de sus miembros e invitados especiales, la búsqueda del análisis plural y del diálogo franco sobre los asuntos internacionales.

En su creación, a la cual concurrió el historiador Arnold Toynbee, el Instituto fue calificado como un acontecimiento muy importante en la historia intelectual de América Latina. Esta afirmación nos invita a realizar un análisis objetivo acerca de lo que ha sido nuestra contribución en 25 años al estudio sistemático de las relaciones internacionales y respecto de cuáles son nuestras tareas para el futuro inmediato.

Un perfil del Instituto en las actuales circunstancias, revelaría que han sido atributos que lo han caracterizado, la búsqueda concien-

\footnotetext{
"Palabras de la Directora del Instituto, en la ceremonia de celebración de su XXV aniversario, efectuada el jueves 12 de diciembre de 1991 en el Salón de Honor de la Casa Central de la Universidad de Chile.
} 
te de la independencia ideológica o de otra índole, tentaciones que facilitan a veces el camino académico, pero que perturban y envician la esencia del trabajo universitario.

En la Universidad de Chile, el Instituto ha seguido una tradición de pluralismo académico, para privilegiar la objetividad y excelencia en el cultivo de las disciplinas que lo definen y ganar la confianza de quienes influyen o adoptan decisiones, mediante voces autorizadas y expertas.

La colaboración de investigadores de otros centros académicos, de profesores invitados nacionales y extranjeros, con diferentes formaciones teóricas, ha garantizado que el Instituto sea una tribuna de pensamiento abierto, requerida desde los más amplios sectores público y privado. Esta forma de trabajo ha evitado las confrontaciones estériles acerca de temas contingentes y ha servido de base al desarrollo de grandes líneas de trabajo, por las cuales se reconoce e identifica a este centro académico. No sin razón algunos de nuestros colaboradores ocupan cargos de exclusiva confianza después de realizar una fecunda vida académica o prestan servicios de asesoría en temas centrales de nuestras relaciones exteriores.

El ser universitario no ha sido siempre fácil para estos propósitos. Lo saben bien los directores que me precedieron y quienes realizaron un aporte extraordinario en la construcción de un modelo de entidad de investigación, docencia y extensión, teniendo que responder a dificultades financieras, de coordinación y administración, con los propios esfuerzos internos.

Sin embargo, el trabajo sustantivo en áreas como la Cuenca del Pacífico, Derecho del Mar, cooperación e integración en América Latina, relaciones hemisféricas, Sistema Antártico, entre otras, le otorgan una identidad particular entre los centros de esta región, identidad que es ampliamente reconocida. Debo destacar el sello especial que adquirió el Instituto bajo la dirección del profesor Francisco Orrego, mencionando asimismo la obra de los profesores Gustavo Lagos, Miguel Otero, Hugo Llanos, Pilar Armanet, Alberto van Klaveren, Rodrigo Díaz Albónico, quienes asumieron la responsabilidad de dirigir una institución o su Programa de Postgrado, en circunstancias siempre cambiantes.

El entorno actual del Instituto no es ciertamente el de 1966, encontrándose la Universidad en una etapa de definición de prioridades y programas de desarrollo, frente al surgimiento o la consoli- 
dación de otros centros académicos de prestigio en nuestro país. Al mismo tiempo, observamos signos de transformación del sistema internacional con nuevas oportunidades económicas y políticas para el país, pero con profunđas interrogantes acerca de las características y los valores que predominarán en el nuevo orden.

Esto significa que el trabajo académico en el ámbito de los estudios internacionales, con alcance multidisciplinario, se sitúa en un medio fértil y ávido de interpretaciones y avances prospectivos.

El Instituto contribuye intelectualmente a esta tarea mediante su revista trimestral editada ininterrumpidamente desde 1967, sus programas de postgrado y especialización, que hoy acogen a más de un tercio de estudiantes extranjeros y a una amplia actividad de extensión, medio práctico de vinculación con la sociedad y de divulgación de nuevos conocimientos. Contribuye asimismo, con una biblioteca actualizada y abierta al mundo, auténtico núcleo de trabajo universitario, el cual esperamos modernizar con la ampliación de nuestra planta física.

Pero el esfuerzo que significa mantener un nivel alto de producción académica y de contribución con ideas pertinentes al análisis de los asuntos internacionales, requiere también de un esfuerzo permanente de renovación del cuerpo de investigadores y de su perfeccionamiento mediante el trabajo activo en el país y en el exterior.

Este es un primer desafío que tiene el Instituto para responder a las necesidades del corto plazo, entre ellas, la reformulación de algunas actividades docentes, el inicio de otras especializaciones y el aprovechamiento de las oportunidades de intercambio académico con universidades y centros extranjeros. Iniciamos dentro de esta línea un proyecto sobre Relaciones Chile-Alemania. La incorporación de investigadores de primera línea que enriquezcan los horizontes de los que hoy día pertenecemos a este centro y tenemos el privilegio de poseer un tiempo completo, la recreación de un régimen de dedicación exclusiva y la posibilidad de asociar como profesores visitantes a distinguidos investigadores externos, son parte de estos objetivos.

El reconocimiento de la complejidad de los fenómenos internacionales y del surgimiento de nuevas áreas para la definición de nuestros intereses, plantean incertidumbres al trabajo académico, llevando muchas veces a optar por la vía fácil de aprovechar la buena imagen conseguida en otras circunstancias y por el esfuerzo de 
académicos que tuvieron un brillante desempeño en el pasado.

Luchar contra esta actitud debe ser una tarea permanente del Instituto, mediante un esfuerzo de autoevaluación sistemático y de justa calificación del resultado alcanzado. Dentro de esta tarea, las de naturaleza administrativa que permiten el funcionamiento normal de una organización, son tan valiosas como otras contribuciones individuales que tienen mayor divulgación.

Este aniversario encuentra al Instituto en una etapa de acomodo dentro de nuevos proyectos universitarios, con una creciente demanda como centro formador de investigadores y especialistas jóvenes y con un potencial de investigación, mediante grupos de trabajo abocados a áreas temáticas seleccionadas cuidadosamente. La constitución de un Comité asesor académico, así como una integración más activa de los egresados de nuestros programas, nos ayudarán, esperamos, eficazmente a estos propósitos.

Cumplimos 25 años después de una corta, pero intensa historia. La que viene, tenemos que hacerla con nuestro esfuerzo, responsabilidad e imaginación. A esa tarea, los invito en forma entusiasta a ustedes. 